\title{
Corruption in Schools and Universities in Kenya
}

\author{
Simon Thuranira Taaliu \\ School of Education and Social Sciences, University of Embu, Embu, Kenya \\ Email: thuranira.simon@embuni.ac.ke
}

How to cite this paper: Taaliu, S.T. (2017) Corruption in Schools and Universities in Kenya. Open Journal of Social Sciences, $\mathbf{5}$, 227-231.

https://doi.org/10.4236/jss.2017.54020

Received: February 21, 2017

Accepted: April 27, 2017

Published: April 30, 2017

Copyright $\odot 2017$ by author and Scientific Research Publishing Inc. This work is licensed under the Creative Commons Attribution International License (CC BY 4.0).

http://creativecommons.org/licenses/by/4.0/

\section{(c) (i) Open Access}

\begin{abstract}
In Kenya, corruption is one of the social problems which permeate all sectors of the economy including education. There is alleged corruption in forms of recruitment, promotion, transfer and deployment of teachers. In schools, both primary and secondary, there is corruption in recruitment of students in form one (especially in the prestigious national secondary schools), supply of materials to the schools, and in national examination. At the universities, the same repeats itself in form of tribalism and ethnicity in employment, promotion and recruitment of students. This state of affairs has led to major reforms being made by the Ministry of Education in Kenya lead by the Cabinet Secretary Dr. Fred Matiang'i. Some of the recommendations include empowering the Ethics and Anti-Corruption Commission (EACC), vetting of Principals and Head teachers, and commitment on the side of the Government to fight corruption.
\end{abstract}

\section{Keywords}

Corruption, Education, Schools, University, Kenya

\section{Introduction}

This paper illuminates on the issue of corruption in the education sector in Kenya and the different ways in which the government has endeavored to tackle the problem. One of the most disturbing problems facing the development of education in Kenya and across Sub-Saharan Africa is corruption. The Teachers Service Commission (TSC) has been ranked as one of most corrupt government agency after the Kenya Police for many years. Corruption is widespread in other areas but it seems more rampant in education because of the number of teachers involved. It was hoped with the new constitution of 2010, corruption would be tackled but nothing much has been achieved yet (Taaliu, 2010) [1]. This article 
articulates the causes of corruption in Kenyan schools and universities and also examines different approaches to curbing this problem. The article recommends a multi-faceted approach to tackling the issue of corruption which does not only affect education but also other sectors of the economy in Kenya.

\section{Corruption in Schools and Universities in Kenya}

\subsection{Introduction}

Corruption has very long lasting consequences because resources are wasted, young people are denied the education they should receive, and those unable to afford bribes are denied access to schooling (both primary and secondary education). A generation of students come to believe that personal effort and merit do not count and that success comes through manipulation, favoritism, and bribery (Chapman 1994) [2].

\subsection{Causes of Corruption in Schools and Universities}

\subsubsection{Admission to schools and Colleges/Universities}

Starting with national exams, it has been found out that there has been a lot of cheating. This was exemplified by the results of both Kenya Certificate of Primary Education (KCPE) and Kenya Certificate of Secondary Education (KCSE) of 2016 where there was drastic reduction of the number of students scoring grade A, due to good supervision of the exams. This means all along there has been a lot of cheating going on in both the exams in public and private schools. In Kenya, due to the importance attached to admission to prestigious high schools and universities, there is a lot of interest in the school a student is admitted in form one. Many parents go all the way to bribing the principals of the national schools for vacancies in these schools. Admission to these national high schools have been seen as a guarantee to admission to public universities which are viewed to be more prestigious than the private ones. Some of the principals of the national schools are coerced by senior government officials to give them admission letters to form one and other classes in their schools through threats and undue influence. Some principals will not hesitate to admit children of relatives, clansmen, tribesmen and therefore fanning corruption and nepotism in the schools (Chapman, 2003) [3].

At the universities, recent reports have indicated that some of the public and private universities have been admitting students for degree programmes without the required minimum of $\mathrm{C}+$ mean grade at Kenya Certificate of Secondary Education (KSCE). More so politicians have been admitted without meeting the minimum requirements. Some of these politicians do not attend lectures and they pay other students to do the academic work for them.

\subsubsection{Academic Dishonesty}

Apart from politicians, there are other Kenyans, like busy CEOs, principal of high schools and other senior people who enroll in the universities but because of the nature of their jobs they have no time to attend lectures and write papers. 
They therefore pay other people to carry out research and write thesis for them. Many universities which are not keen during defence are duped that this work belongs to the people presenting it. At the universities also there has been the sub-culture of sex for grades. This is where by students offer sexual favours to lecturers to award them good marks. Sometimes the male students pay for good grades through monetary values because they are not able to offer sexual favours especially to the predominantly male lecturers.

\subsubsection{Recruitment and Promotion of Staff}

Promotion of staff in both schools and universities is done on merit in most cases, but there are cases of ethnicity, nepotism and corruption. The Teachers Service Commission (TSC) [4] is charged with the responsibility of recruiting, disciplining, promotion and deployment of teachers. These processes are mired in corruption and nepotism all the way from the school board of management which recruits teachers on behalf of TSC. Most of the teachers recruited are from that county where the school is located, leaving very little room for outsiders being recruited. The reason is that all the board members are drawn from within the locality and naturally they favor one of their won to be recruited at the expense of people from outside the county or even the sub-county. In the universities it is no different. The National Cohesion and Integration Commission led by Francis Ole Kaparo has been on these cases but no progress has been done in terms of prosecuting the culprits.

\subsubsection{Transfer of Teachers}

The Teachers Service Commission (TSC) has devolved some functions like transfers of teachers to the County Teachers Service Commission Director. This was previously done by TSC headquarters, but now it's like the corruption has been devolved to the counties. For teachers to be transferred from one school to another, they have to part with some money. This is silently done, because the giver and the taker of the bribe knows he/she is guilty so they would not like to disclose it. Promotions also are done through interviews, but these are just rubber stamps because you will find a school being headed by diploma holder when there are $\mathrm{PhD}$ holders in the same staff room.

\subsubsection{Supply of Materials}

Many tenders in schools are issued through public tendering. This is the ideal situation, but it does not happen all the time. Some of the schools especially secondary schools, the tenders of supplying materials are given to cronies or proxies of the principals and chairpersons of the Board of Management of the schools. This is done in complete breech of public procurement tendering procedure which spells out conflict of interests in the tendering process.

\subsubsection{Fees}

The Ministry of Education has set the minimum and maximum fees to be paid by students in both primary and secondary schools. Many principals of high school have continued to charge more than the recommended fee. Some of the 
schools have hidden charges which are not included in the official receipts. Some of these hidden charges include tuition fees which has been outlawed by the government but continue to be levied by most primary schools.

\subsubsection{Moral Corruption}

In some of the schools there is a silent moral decay. This decay is in form of sexual relationships between students and teachers. Some of these cases become known to authorities and disciplinary procedure are instituted but at the end of it all the culprits are released and find their way back to the schools. In some instances, the victims' family settle the cases out court, where the amorous teachers are asked to pay fines to the girls' family or marry her.

\subsubsection{Absentee Teachers}

Many teachers in both primary and secondary schools are chronically absent from schools. Head teachers fail to take measures, because some of the teachers will corrupt their way back to schools even if they are found guilty of being away from school without permission. In some of the schools teachers are found to be engaged in businesses during school time and at the expense of their work.

\section{Recommendations}

Academic dishonesty can be checked by the universities being very strict especially by using the anti-plagiarism software which can detect work which does not belong to someone. The universities should stick to the admission criteria and the Commission for University Education should carry its own full mandate of inspecting the universities both private and public.

According to Transparency International Kenya (TI-K) [5] education is key in preventing corruption, and that education in good governance, ethics and integrity for students in schools can help break the cycle of corruption and prepare them for future leadership. Against this background TI-K has initiated integrity clubs for students in ethical and integrity learning in schools. TI-Kenya has supported and strengthened activities of 80 integrity clubs across three counties in the review period; 30 in Trans Nzoia County, 29 in Kisumu County, and 21 in Kwale County. Across the three counties, integrity clubs have contributed to improved discipline and responsiveness among the learners (TI-K p.27).

Just as high cadre police officers are being vetted today in Kenya, even principals of high schools should be vetted to determine their suitability. Their life styles should be audited to establish the source of their wealth. Many of the principals live luxurious lives, which is are far beyond their earnings. The Ministry of Education and the Government of Kenya should set up an Oversight Commission like the Police Oversight Committee one to investigate cases of abuse of office by school principals.

The TSC should endeavor to make sure that principals do not overstay in one schools for long. There has been instances where a principal starts as a student on teaching practice, he/she is employed in the same school, promoted to a head of department, deputy principal and retires in the same school as the principal. 
This is career spanning over 40 years in the same school!

The Ministry of Education should ensure the guidelines on fees are followed by the schools. Most parents have no option when asked to pay the extra fees because if they fail their children are sent away from school. The Dr. Kilemi Mwiria's recommendations on fees guidelines need to be implemented in the schools to be able to achieve a level playing ground to all students and parents. The Ethics and Anti-Corruption Commission (EACC) should be given more powers to prosecute cases and the Judiciary to jail people found involved in corrupt deals. The Judiciary should also work independently without the Executive undue influence in the judgements.

\section{Conclusion}

The issue of corruption in Kenya is endemic in that it is very widespread to almost all sectors of the economy. There seems to be lack of commitment from the government to fight corruption, because even with government units like Ethics and Anti-Corruption Commission of Kenya (EACC) very little seem to have been achieved. There is need for commitment from the top to fight corruption without which the ordinary Kenyan does not see anything wrong in giving and receiving of bribes.

\section{References}

[1] Taaliu, S.T. (2011) Perspectives on the Teaching Profession in Kenya: Perception, Status, and Job (Dis) Satisfaction. Lambert Academic Publishers, Germany.

[2] Chapman, D.W. (1994) Reducing Teacher Absenteeism and Attrition: Causes, Consequences and Responses. UNESCO, IIEP, Paris.

[3] Chapman, D.W. (2003) Stealing an Education: Corruption in Education. University of Minnesota, Minneapolis.

[4] Teachers Service Commission (TSC) (2017) https://www.tsc.go.ke/

[5] Transparency International (2015) Promoting Integrity in Schools. https://www.tikenya.org/

Submit or recommend next manuscript to SCIRP and we will provide best service for you:

Accepting pre-submission inquiries through Email, Facebook, LinkedIn, Twitter, etc. A wide selection of journals (inclusive of 9 subjects, more than 200 journals)

Providing 24-hour high-quality service

User-friendly online submission system

Fair and swift peer-review system

Efficient typesetting and proofreading procedure

Display of the result of downloads and visits, as well as the number of cited articles

Maximum dissemination of your research work

Submit your manuscript at: http://papersubmission.scirp.org/

Or contact jss@scirp.org 